\title{
Increasing the Quality of the Production Steering Wheel Castings Using Simulation Calculati- ons of Solidification
}

Iva Nová, Jiří Machuta, Josef Horáček,

Faculty of Mechanical Engineering, Technical University of Liberec, Studentská 2, 46117 Liberec. Czech Republic. Email: jiri.machuta@tul.cz,iva.nova@tul.cz,josef.horacek1@tul.cz

This paper deals with the solidification and cooling of steering wheel castings. Castings of steering wheel are manufactured by high pressure die-casting of magnesium alloys. Further the paper shows a simulation calculation of solidification and cooling of the casting made of the AM 50 magnesium alloy. The results of simulation calculations are using the QuikCAST programme. The required values thermo-physical variables were taken from the databank program. It was found that filling of the mould due to the pressure conditions is very fast. The Solidification is affected with a thermic hypothermia of the melt. The results of simulation calculations give approximate information about the process of solidification high pressure die casting. From the simulation results it is obvious that solidification in the form takes place according to foundry assumptions.

The paper also gives a characteristic microstructure of material (MgAl5Mn), consists of a solid solution $\alpha$ and an eutectic $\left(\alpha+\beta, \beta\right.$ is intermetallic phase $\left.\mathrm{Mg}_{17} \mathrm{Al}_{12}\right)$. The contribution has been created during the SGS 21005 project.

\section{Acknowledgement}

This paper is published with the support of the project SGS 21005.

\section{Reference}

[1] HORÁČEK, J. (2010). Measuring and simulation calculations field of temperature cast the shape of the plate. 7. Mezinárodní PhD konference, 47. Slévárenské dny 23. - 24. Června 2010, Sborník příspěvků ISBN 978-80904020-6-5.

[2] FRIEDRICH, H., MORDIKE, L. (2006). Magnesium technology. Springer-Verlag Berlin-Heidelberg 2006, ISBN 10-3-540-20599-3.

[3] FRIEDRICH, H, SCHUMANN, S. (2001). Research for a "new age of magnesium" in the automotive industry, Journal of Material Processing Technology, 117, 276-281.

[4] ŻYDEK, A., KAMIENIAK, J., BRASZCYŇSKA, K.N. (2011). Evolution of Mg-5Al-0.4Mn microstructure after rare earth elements addition, Archiver of Foundry Engineering. ISSN (1897-3310), Volume 11, Issue 2, pp. 157 $-160$.

[5] ANDREAS STIHL AG \& Company The materials and this properties - magnesium alloys (In Germany) Comparation training documents .

[6] RAGHAVAN, V. (2010). Al-Mg-Mn (Aluminum-Magnesium-Manganese), Journal of Phase Equilibria and Diffusion Vol. 31 No. 1, p.46.

[7] KIELBUS, A., RZYCHOŇ, T., CIBIS, R. (2006). Microstructure of AM50 die casting magnesium alloy. Journal of Achievements in Materials and Manufacturing Engineering. Volume 18, Issue 1-2, September-October.

[8] ALUMINIUM RHEINFELDEN GmbH Rheinfelden alloys Verkauf und Kundenberatung Rheinfelden (In Germany) Promotional material of company:, Germany.

[9] DRÁPALA, J., KUCHǍ̌, L., TOMÁŠEK, K., TROJANOVÁ, Z. (2004). Hořčík, jeho slitiny a binární systémy hořčík - přměsy. (Magnesium, his alloys and bingy system magnesium-ingredient) (in Czech), VSB-TU Ostrava, s. $6-31$.

[10] ESI GROUP Technical materials foundry simulation program QuikCAST ESI Group Headquarters (In France).

[11] MICHNA, Š. (2010). Strukturní analýza a vlastnosti předslitiny AlCa10 (in Czech), (Structural analysis and properties pre-alloy AlCa10), Strojírenská technologie, s. 175-176.

[12] VOJĚCH, D., KUBASEK, J., VODĚROVÁ, M. (2012). Structural mechanical and in vitro corrosion characterization of as cast magnesium based alloy for temporary biodegradable medicinal implants (in Czech), Manufacturing Technology. Vol.12, No 13 p. 285-292. ISSN 1213-2489.

[13] SLÁDEK, A, FABIAN. P., PASTIRČÁK,R., BREZNIČAN,M. (2012). The Roundness and microstructure of Thin-wall Bearinng (in Czech), Manufacturing Technology. Vol. 12, No 13 p. 237-241. ISSN 1213-2489. 